\title{
Study of Some Indicators of Environmental Pollution of Surface Soil for the City of Touggourt (Southeast Algeria)
}

\author{
A. Benarabi*†, M. S. Nili** and A. Douadi*** \\ *VPRS Laboratory, Faculty of Mathematics and Material Science, Kasdi Merbah University, Ouargla 30000, Algeria \\ **Laboratory of Biodiversity and Biotechnology Applications in the Agricultural Field, Faculty of Natural and Life \\ Sciences, Echahid Hamma Lakhdar University, El-Oued 39000, Algeria \\ ***Pollution \& Waste Treatment Laboratory, Faculty of Mathematics and Material Science, Kasdi Merbah University, \\ Ouargla 30000, Algeria
}

†Corresponding author. A. Benarabi; abdelkrim.benarabi@gmail.com

Nat. Env. \& Poll. Tech.

Website: www.neptjournal.com

Received: 03-12-2020

Revised: $02-04-2021$

Accepted: 11-04-2021

Key Words:

Potentially toxic metals

Contaminated soil

Pollution indicators

Touggourt city

\begin{abstract}
Soil is contaminated with various potentially harmful metals (PTMs). Therefore, the adequate protection of soil from contamination is imperative, as the soil is regarded as the primary cradle for living and environmental balance. Accordingly, the purpose of this study was to assess the contamination level by PTMs in Touggourt city, where soil samples have been collected randomly from 18 sites. These sites included manufacturing companies and institutions belonging to the industrial region of Touggourt city. The concentrations of six PTMs - zinc $(\mathrm{Zn})$, iron $(\mathrm{Fe})$, cobalt $(\mathrm{Co})$, copper $(\mathrm{Cu})$, lead $(\mathrm{Pb})$ and manganese $(\mathrm{Mn})$ were assessed using the atomic absorption spectrophotometer (AAS) instrument as well as the application of the modern pollution indices such as CF (Contamination Factor), PLI (Pollution Load Index) and EF (Enrichment Factor). The highest values of contamination factor (CF) for $\mathrm{Zn}, \mathrm{Fe}, \mathrm{Co}, \mathrm{Cu}$, and $\mathrm{Pb}$ were $0.605,1.605,0.277,0.05,0.438$, and 0.01 , respectively, and the highest value of pollution load index (PLI) was 0.139 , while the results of enrichment factor (EF) for the $\mathrm{Zn}, \mathrm{Mn}$, $\mathrm{Co}, \mathrm{Cu}$ and $\mathrm{Pb}$ metals were $2.608,0.060,0.740,0.122$, and 2.358 , respectively. According to these pollution indices, the results of this study have indicated that human effects or industrial wastes and traffic, in particular, were the sources of heavy metal contaminating the studied region.
\end{abstract}

\section{INTRODUCTION}

The massive increase in the volume of pollutants as a result of human activities on the one hand, and the increased level of potentially toxic metals (PTMs) in soil, water, and air, on the other hand, has sparked a worldwide interest in studying these toxic metals (Fang \& Lin 2002, Woitke et al. 2003, Santos et al. 2002, Adamo et al. 2005). PTMs pollution has become a worldwide problem because these metals are considered non-organic pollutants with non-degradable nature, so they persist for long times and mostly accumulate in high levels in the environment, which leads to harmful effects (Ayangbenro \& Babalola 2017).

PTMs are considered one of the most dangerous soil pollutants, which lead to the change in some of the soil physicochemical properties, However, some of these metals are essentially important for life but in low concentrations, which makes it one of the most serious ecological problems at all (Zheljazkov \& Nielsen 1996, Adamo et al. 2018). Therefore, we consider the soil polluted when it contains high concentrations of the PTMs, regardless of the different sources of such metals, as it becomes toxic for humans, plants, and animals (Wuana \& Okieimen 2011, Dehghani et al. 2017).

Soil is considered clean when the concentration of the PTMs is below the environmental level with a value similar to or lower the value naturally present. The background value is the total metal concentration obtained from soil, which is not affected by human activities (Silva et al. 2019).

Accordingly, many researchers and those interested in the environmental pollution field emphasized the necessity of assessing the pollution level of the non-agricultural area's soil with PTMs (Kelly et al. 1996, Chen et al. 1997, Manta et al. 2002).

Based on the fact that PTMs pollution originating mainly from industrial activities is considered one of the most serious problems that the world suffering from in the last few decades, the purpose of this study was, therefore, to investigate the source of topsoil contamination with some PTMs in Touggourt city by measuring some of the pollution indices, such as Contamination Factor (CF) (Victoria et al. 2014), Pollution Load Index (PLI) (Gong et al. 2008) and 
Enrichment Factor (EF). The latter is considered a potent indicator for distinguishing and detecting whether the source of heavy metal pollution is anthropogenic or natural (Ozkan et al. 2012).

Touggourt city is located in the north Algerian Sahara. It is also a part Valley and known as the Upper Oued Righ. Touggourt city is characterized by having a central location, in which it lies at the junction between two national roads; N3 and N16 that connect many cities (Boulghobra et al. 2016). Accordingly, Touggourt city witnessed massive human movements throughout history and rapid expansion of urbanization and industrialization over the last decades. The Touggourt area is about $404 \mathrm{~km}^{2}$, equivalent to $0.25 \%$ of the state area. According to the $2019 / 2020$ census, Touggourt district has a population of 200,007 .

\section{MATERIALS AND METHODS}

\section{Study Area}

Touggourt, the capital of Oued Righ that literally means "gateway" as the historians called it because of the importance of its geographical location, which makes it a transit point and commercial center. Far away about $650 \mathrm{~km}$ from the capital Algiers between longitudes 5 ${ }^{\circ} 59^{\prime} 20$ “ and 6 '48' 49" east of the Greenwich meridian and between two latitudes $33^{\circ} 12^{\prime} 89^{\prime \prime}$ and $33^{\circ} 85^{\prime} 67^{\prime \prime}$ north of the equator. It is 65-80 $\mathrm{m}$ above sea level (Daniel 1978).

In addition, the topography of the region and its suburbs is characterized by its diversity in terms of soil and vegetation as well as numerous sand dunes that surround it from east to west. It is interspersed with salt plains and some barren mud hills (Abdelhamid 1999).

Besides the agricultural land use in Touggourt, there are a lot of economic activities going on, such as oil and natural gas industries and others (Fig. 1). Hence, there are many anthropogenic sites and activities, such as fuel filling stations, factories, waste dumpsites, cars, markets, etc.

\section{Samples Collection, Preparation, and Analysis}

Surface soil samples were collected from 18 sites after removing leaves, grasses, and other strange items at a depth of $0-10 \mathrm{~cm}$ using a soil auger. Table 1 provides the geographic

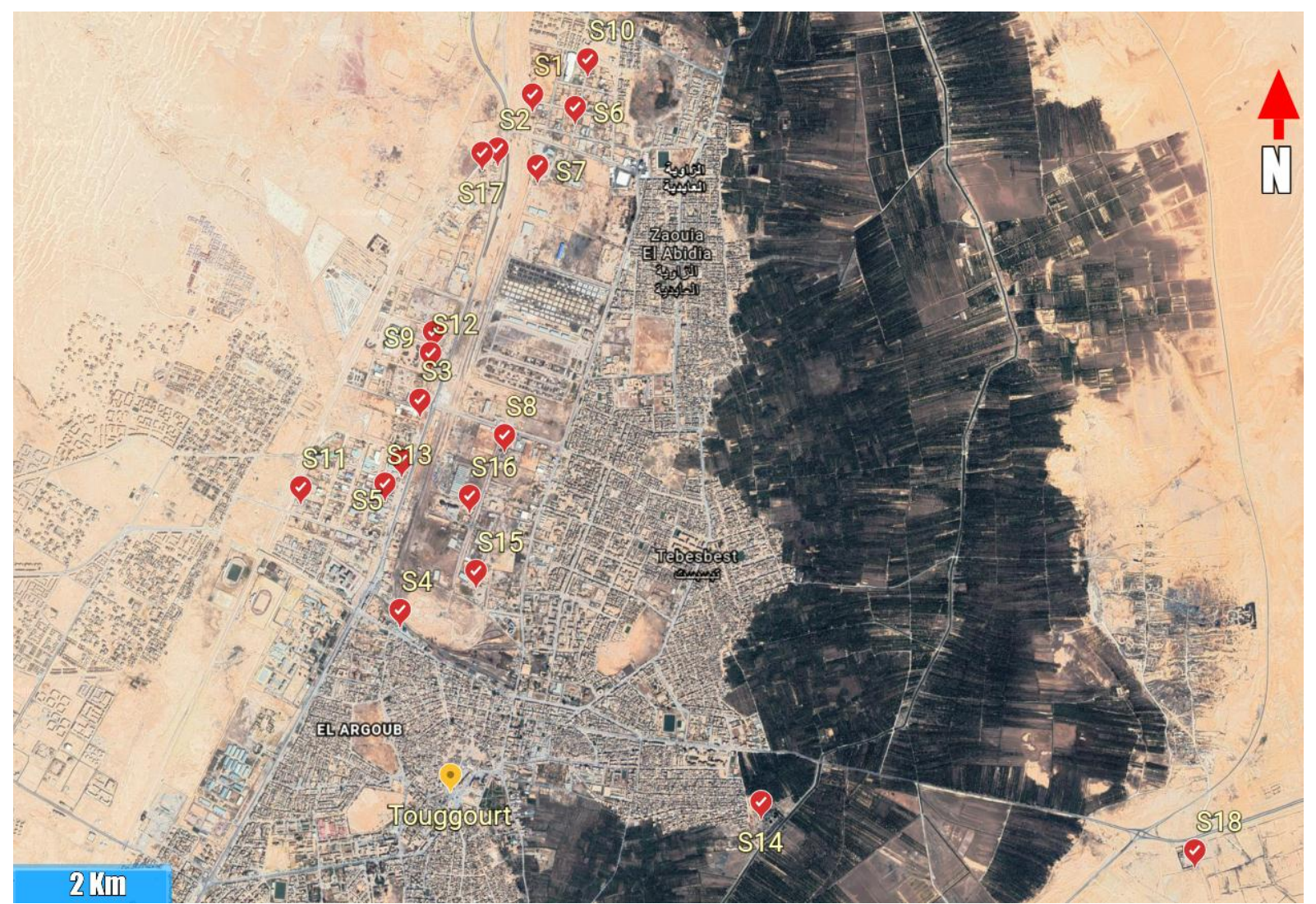

Fig. 1: Map of Touggourt city showing the locations of the sampling sites. 
coordinates of sampling sites, while Fig. 1 represents the map of the study area with sampling sites on it. At each site, the samples were collected at random from 5 different points and then bulked together to ensure the representativeness and adequacy of samples. Bulked soil samples were placed on clean polyethylene plastic bags and sent to the lab for analysis. Standards were used for analysis according to the method used by Gee and Bauder (Galindo et al. 2011). First, the samples were air-dried, ground, kept in an electronic oven at $120^{\circ} \mathrm{C}$ for $24 \mathrm{~h}$ until the weight stabilized and sieved through a $0.2 \mu$ sieve. Second, the samples were digested with acidic aqua regia solution (prepared from $\mathrm{HCl}$ and $\mathrm{HNO}_{3}$ in ratio 1:3), where $2 \mathrm{~g}$ of the soil were weighted into a clean bottle. $15 \mathrm{~mL}$ of aqua regia were measured and added to the bottle, then the mixture was heated at a temperature of $120^{\circ} \mathrm{C}$ for $2 \mathrm{~h}$, and then cooled at room temperature. Third, the mixture was filtered through $42 \mu$ filter paper and kept in sealed plastic bottles (NOMA 2019). The concentrations of PTMs in these samples were detected using a flame atomic absorption spectrophotometer working with acetylene gas (Perkin Elmer, AA 900T). All tests for measuring the concentration of the following PTMS: Zn, $\mathrm{Co}, \mathrm{Fe}, \mathrm{Cu}, \mathrm{Pb}$ and $\mathrm{Mn}$ were done in the Center for Scientific and Technical Research on Arid Regions (CRSTRA), Biskra (Algeria).

Table 1: Sampling sites names and geographic coordinates.

\begin{tabular}{|c|c|c|}
\hline $\begin{array}{l}\text { Sampling } \\
\text { site }(\mathrm{s})\end{array}$ & Longitude & Latitude \\
\hline S1 & E $6^{\circ} 43^{\prime} 89^{\prime \prime}$ & N 33 $85^{\prime} 67^{\prime \prime}$ \\
\hline S2 & E $6^{\circ} 36^{\prime} 61^{\prime \prime}$ & N 33 $82^{\prime} 77^{\prime \prime}$ \\
\hline S3 & E $5^{\circ} 60^{\prime} 86^{\prime \prime}$ & N $33^{\circ} 13^{\prime} 45^{\prime \prime}$ \\
\hline S4 & E $6^{\circ} 35^{\prime} 37^{\prime \prime}$ & N $33^{\circ} 65^{\prime} 55^{\prime \prime}$ \\
\hline S5 & E $6^{\circ} 36^{\prime} 49^{\prime \prime}$ & N 33 $81^{\prime} 57^{\prime \prime}$ \\
\hline S6 & E $6^{\circ} 35^{\prime} 89^{\prime \prime}$ & N 33 $74^{\prime} 23^{\prime \prime}$ \\
\hline S7 & E $6^{\circ} 48^{\prime} 49^{\prime \prime}$ & N 33 $82^{\prime} 35^{\prime \prime}$ \\
\hline S8 & E $5^{\circ} 59^{\prime} 23^{\prime \prime}$ & N $33^{\circ} 16^{\prime} 87^{\prime \prime}$ \\
\hline S9 & E $6^{\circ} 35^{\prime} 45^{\prime \prime}$ & N 33 $75^{\prime} 67^{\prime \prime}$ \\
\hline S10 & E $6^{\circ} 35^{\prime} 95^{\prime \prime}$ & N 33 $10^{\prime} 47^{\prime \prime}$ \\
\hline S11 & E 6 $62^{\prime} 60^{\prime \prime}$ & N 33 $72^{\prime} 59^{\prime \prime}$ \\
\hline S12 & E $6^{\circ} 55^{\prime} 81^{\prime \prime}$ & N $33^{\circ} 75^{\prime} 52^{\prime \prime}$ \\
\hline S13 & E $6^{\circ} 35^{\prime} 38^{\prime \prime}$ & N 3373'91'" \\
\hline S14 & E 6 $36^{\prime} 57^{\prime \prime}$ & N $33^{\circ} 55^{\prime} 64^{\prime \prime}$ \\
\hline S15 & E $6^{\circ} 40^{\prime} 50^{\prime \prime}$ & N $33^{\circ} 76^{\prime} 18^{\prime \prime}$ \\
\hline S16 & E $6^{\circ} 43^{\prime} 77^{\prime \prime}$ & N $33^{\circ} 85^{\prime} 39^{\prime \prime}$ \\
\hline S17 & E $6^{\circ} 34^{\prime} 19^{\prime \prime}$ & N $33^{\circ} 76^{\prime} 46^{\prime \prime}$ \\
\hline S18 & E $5^{\circ} 59^{\prime} 20^{\prime \prime}$ & N $33^{\circ} 12^{\prime} 89^{\prime \prime}$ \\
\hline
\end{tabular}

\section{Pollution Indices}

Assessment of the metal contamination in the soil is generally carried out by comparing the measured concentrations of PTMs in the tested soil with the geochemical background values (Pobi et al. 2020). The reference value used in the present study is based on the average continental crust of worldwide soils (Kabata-Pendias et al. 2007). Some pollution indices were used in this study, such as Contamination factor (CF), Enrichment factor (EF), and Pollution Load Index (PLI), which can determine the degree of PTMs contamination in Touggourt industrial soils and whether the source of pollution is anthropogenic or natural (Keshav \& Rama 2016).

\section{Contamination Factor $(\mathbf{C F})$}

The contamination factor is used the categorize the metals pollution degree in the study area. This factor can be computed using Equation (1):

$$
\mathrm{CF}=(\mathrm{Cm} 1) \text { sample/Cm)background }
$$

In the above equation, the " $(\mathrm{cm})$ sample" refers to the concentration of specific metal in the soil, while " $(\mathrm{cm})$ Background" refers to the geochemical background reference value of the same metal (Chandrasekaran et al. 2015, Liu et al. 2005). As shown in the table below, the contamination factor was divided into four categories (Table 2).

\section{Enrichment Factor (EF)}

The enrichment factor is considered one of the geochemical indices used for the assessment of anthropogenic pollution (Gałuszka \& Migaszewski 2011). It can be computed from Equation (2):

$$
\mathrm{CF}=(\mathrm{Cm} 1) \text { sample/Cm)background }
$$

Where $(\mathrm{Cm} / \mathrm{Cref}$ Sample) is the ratio of heavy metal to the reference metal concentration in the same sample and $(\mathrm{Cm} / \mathrm{Cref})$ background is the ratio of the heavy metal to the reference metal concentration in a suitable geometrical background value (Zakir et al. 2008). Many metals have been proposed to be the potential conservative reference metal and used in literature for the measurement of the enrichment factor, such as Fe, Mn, Aluminum (Al), Scandium (Sc) Manganese (Mn), and others (Schiff \& Weisberg 1999, Chen et al. 2020). Among these metals, $\mathrm{Fe}$ and $\mathrm{Al}$ are the most frequently used ones. The enrichment factor is classified into 5 categories as shown in Table 3.

\section{Pollution Load Index (PLI)}

Pollution load index (PLI) indicator measures the cumulative metal pollution load in the study area and gives a clear picture 
about the extent of PTMs toxicity in the tested soil sample through assessment of the contamination status of the soil so that the appropriate procedures for environmental protection could be taken (Hossain et al. 2015). PLI can be computed by using the CF value of every metal (Usero et al. 2000). This index is expressed by Equation (3):

$$
\mathrm{PLI}=(\mathrm{CF} 1 * \mathrm{CF} 2 * \mathrm{CF} 3 * \ldots . . \mathrm{CFn})
$$

Where $\mathrm{n}$ represents the number of metals. Parker et al. (2008) classified the Pollution Load Index (PLI) into 7 categories as shown in Table 4.

\section{Statistical Analysis}

Results obtained from all samples were subjected to descriptive (mean, standard deviation, and ranges) statistics.

\section{RESULTS AND DISCUSSION}

\section{Assessment of Level of Soil Contamination}

The concentrations of PTMs in the surface soil samples taken from the study area are shown in Table 5. The spatial distribution of PTMs ( $\mathrm{Zn}, \mathrm{Mn}, \mathrm{Pb}, \mathrm{Cu}, \mathrm{Co}$, and $\mathrm{Cu}$ ) from the industrial region in Touggourt were compared with their geochemical background reference level. These results indicate the variation in the average concentration of the tested PTMs, where the highest average concentration for $\mathrm{Zn}$ was $17.61 \mathrm{mg} \cdot \mathrm{ml}^{-1}, 9.48 \mathrm{mg} \cdot \mathrm{ml}^{-1}$ for $\mathrm{Fe}, 5.6 \mathrm{mg} \cdot \mathrm{ml}^{-1}$ for $\mathrm{Mn}, 2.36$ $\mathrm{mg} \cdot \mathrm{ml}^{-1}$ for $\mathrm{Pb}, 0.7 \mathrm{mg} \cdot \mathrm{ml}^{-1}$ for $\mathrm{Cu}$ and $0.64 \mathrm{mg} \cdot \mathrm{ml}^{-1}$ for $\mathrm{Co}$. Except for copper and cobalt, the average concentrations of the tested PTMs in the study area exceed their threshold limit values (TLV) in Algeria (OJPDRA 2006).

This contamination is a result of the solid, liquid, and gaseous wastes from the various industrial facilities within the study area that are derived from natural and anthropogenic inputs. For a better assessment of the anthropogenic inputs, computing of some pollution indices represented by the Contamination factor (CF), Pollution Load Index (PLI), and Enrichment factor (EF) is required.

\section{Contamination Factor $(\mathrm{CF})$}

The contamination factor expresses the level of soil

Table 2: Categories of contamination factor (CF).

\begin{tabular}{|lll|}
\hline Class & CF value & Category \\
\hline Class 1 & $\mathrm{CF}<1$ & Low contamination factor \\
Class 2 & $1<\mathrm{CF}<3$ & Moderate contamination factor \\
Class 3 & $3<\mathrm{CF}<6$ & Considerable contamination factor \\
Class 4 & $\mathrm{CF}>6$ & Very high contamination factor \\
\hline
\end{tabular}

contamination with any heavy metal and also indicates the level of anthropogenic pollution of specific soil (Adamu et al. 2014). The CF values of metals in various sampling sites are presented in Table 6. From the results shown in Table 7, it can be noticed that the average $\mathrm{CF}$ values follow the ascending order of $\mathrm{Mn}<\mathrm{Cu}<\mathrm{Co}<\mathrm{Pb}<\mathrm{Fe}<\mathrm{Zn}$ as shown in Table 7. All of these values belong to the low contamination factor category, $\mathrm{CF}<1$. This result indicates that the Earth's crust rocks are the main source of these metals (Szefer et al. 2008). The relatively higher CF value in the study area was for ZInc (Zn), which could be a result of the petroleum compounds emissions. In addition, the lowest $\mathrm{CF}$ value was for Manganese (Mn), being stable metal in the Earth's crust.

\section{Pollution Load Index (PLI)}

PLI represents the number by which the heavy metal concentration in the soil exceeds its background value and it gives a clear picture of the extent of the heavy metal toxicity in the soil. It also represents the soil contamination in a certain location and it has many definitions, where it has been defined by Hakanson (1980) as the sum of contamination factor values and it has also been defined as the arithmetic mean or the geometric mean of the analyzed pollutants (Mmolawa et al. 2010).

According to the results of PLI shown in Table 8, the PLI values of all soil samples were $0<\mathrm{PLI}<1$ and belong to the low contamination category $(\mathrm{PLI}<1.5)$. Since the pollution load index value is less than 1.5 (the error correction factor used in classification, Table 4), It does not necessarily mean that there is no intervention of anthropogenic activities in pollution induction. According to Muller (1969), PLI values less than 1.5 indicate that the source of the heavy metal is entirely from natural processes, while values greater than 1.5 suggest that the source is more likely to be anthropogenic. However, these low PLI values will not reflect the non-contamination of the studied soil samples with industrial wastes. In addition, the pollution load index value did not reach higher values because the contamination factor $(\mathrm{CF})$ values of PTMs in the study area are very close to their background values in the reference soil.

Table 3: Categories of enrichment factor (EF).

\begin{tabular}{|lll|}
\hline Class & EF value & Category \\
\hline Class 1 & $\mathrm{EF}<2$ & Deficiency to minimal enrichment \\
Class 2 & $2 \leq \mathrm{EF}<5$ & Moderate enrichment \\
Class 3 & $5 \leq \mathrm{EF}<20$ & Significant enrichment \\
Class 4 & $20 \leq \mathrm{EF}<40$ & Very high enrichment \\
Class 5 & $\mathrm{EF} \geq 40$ & Extremely high enrichment \\
\hline
\end{tabular}




\section{Enrichment Factor (EF)}

The enrichment factor is widely used to confirm the presence and assess the magnification of the anthropogenic contamination of soil with PTMs, i.e. its value determines the degree of contamination (Barkett \& Akün 2018). The results of EF of surface soils are represented in Table 9, where Fe has been chosen as a reference element for calculation. Akoto et al. (2008) illustrated that the EF values range between 0.5-1.5 indicate that the PTMs originate from natural geological processes, while the EF values greater than 1.5 indicate that the sources of the PTMs are anthropogenic processes. The EF values of PTMs in the soil of the study area in the following order $\mathrm{Mn}<\mathrm{Cu}<\mathrm{Co}<\mathrm{Pb}<\mathrm{Zn}$ as shown in Table 10

As given in Table 9, a significant enrichment is observed for $\mathrm{Zn}$ (at S7, S12, and S18), a moderate enrichment is observed for $\mathrm{Zn}$ and $\mathrm{Pb}$ (at most of the tested sites), and a

Table 4: Categories of Pollution Load Index (PLI).

\begin{tabular}{|lll|}
\hline Class & PLI value & Category \\
\hline Class 1 & PLI $<1.5$ & Clean or very low pollution \\
Class 2 & $1.5 \leq \mathrm{PLI}<2$ & Low pollution \\
Class 3 & $2 \leq \mathrm{PLI}<4$ & Moderate pollution \\
Class 4 & $4 \leq \mathrm{PLI}<8$ & Significant pollution \\
Class 5 & $8 \leq \mathrm{PLI}<16$ & Very high pollution \\
Class 6 & $16 \leq \mathrm{PLI}<32$ & Extremely high pollution \\
Class 7 & $\mathrm{PLI} \geq 32$ & Excessive pollution \\
\hline
\end{tabular}

Table 5: Average concentration of PTMs in Touggourt industrial soil.

\begin{tabular}{|c|c|c|c|c|c|c|}
\hline \multirow[t]{2}{*}{ Sampling site } & \multicolumn{6}{|c|}{ Metal concentration (ppm) } \\
\hline & $\mathrm{Mn}$ & $\mathrm{Pb}$ & $\mathrm{Cu}$ & Co & $\mathrm{Fe}$ & $\mathrm{Zn}$ \\
\hline S1 & 7.365 & 2.025 & 0.506 & 0.447 & 7.823 & 11.820 \\
\hline S2 & 3.856 & 0.950 & 0.500 & 0.470 & 3.463 & 4.206 \\
\hline S3 & 3.862 & 0.562 & 0.445 & 0.384 & 3.757 & 6.225 \\
\hline S4 & 7.467 & 2.937 & 0.645 & 0.636 & 6.283 & 14.76 \\
\hline S5 & 6.041 & 0.817 & 2.881 & 2.777 & 80.25 & 24.86 \\
\hline S6 & 7.044 & 0.875 & 0.703 & 0.538 & 6.908 & 22.50 \\
\hline S7 & 5.392 & 4.084 & 0.573 & 0.499 & 5.235 & 52.49 \\
\hline S8 & 2.254 & 0.667 & 0.260 & 0.285 & 2.338 & 9.205 \\
\hline S9 & 3.300 & 1.534 & 0.487 & 0.508 & 4.779 & 11.06 \\
\hline $\mathrm{S} 10$ & 1.212 & 0.917 & 0.292 & 0.426 & 2.237 & 8.572 \\
\hline S11 & 25.96 & 6.134 & 0.866 & 1.011 & 19.74 & 41.84 \\
\hline $\mathrm{S} 12$ & 3.068 & 6.920 & 1.394 & 0.350 & 5.302 & 42.37 \\
\hline S13 & 3.821 & 2.171 & 0.286 & 0.338 & 2.967 & 16.42 \\
\hline S14 & 1.416 & 1.138 & 0.319 & 0.370 & 4.455 & 5.222 \\
\hline S15 & 3.848 & 3.118 & 0.579 & 0.367 & 3.187 & 9.011 \\
\hline S16 & 3.464 & 1.151 & 0.348 & 0.377 & 2.879 & 5.620 \\
\hline S17 & 9.276 & 3.033 & 1.059 & 0.926 & 8.245 & 22.330 \\
\hline S18 & 2.106 & 3.430 & 0.372 & 0.746 & 0.770 & 8.480 \\
\hline $\begin{array}{l}\text { Background refer- } \\
\text { ence level (mg/kg) }\end{array}$ & 900 & 14 & 55 & 10 & 50 & 70 \\
\hline $\begin{array}{l}\text { Threshold limit val- } \\
\text { ue (TLV) }(\mathrm{mg} / \mathrm{ml})\end{array}$ & 1 & 0.5 & 1 & 2 & 1 & 2 \\
\hline
\end{tabular}


moderate enrichment for Co (at S18). However, the obtained results of EF for remaining PTMs showed very low enrichment $(\mathrm{EF}<1)$ in all industrial soils. Soil samples with $\mathrm{EF}>$ 2 for a specific metal are considered contaminated with this metal (Zakir et al. 2008). Accordingly, as shown in Table 10 , most of the surface soil samples taken from the studied sites are considered contaminated with $\mathrm{Pb}$ and $\mathrm{Zn}$, where the highest EF value for $\mathrm{Zn}$ was 2.608 (Moderate enrichment), while the highest $\mathrm{EF}$ value for $\mathrm{Pb}$ was 2.358 (Moderate enrichment). On the other hand, the highest $\mathrm{EF}$ values for $\mathrm{Cu}$ and $\mathrm{Mn}$ were recorded as 0.122 and 0.060 , respectively (Deficiency to minimal enrichment) and the highest EF value for Co was recorded as 0.740 (Significant enrichment). The abundance of $\mathrm{Zn}$ and $\mathrm{Pb}$ in the soil of the Touggourt industrial region is low, but their higher enrichment suggests that $\mathrm{Zn}$ and $\mathrm{Pb}$ contamination in the study area is derived from various anthropogenic activities, such as industrial zones, especially the petroleum ones as well as gaseous emissions from traffic (Wang et al. 2017). are more likely to be the source of PTMs in the study area.

Touggourt city is characterized by the presence of high traffic density (cars, trucks, buses, agricultural tractors, motorcycles, etc.), besides the excessive use of brakes due to the irregular dump sites. $\mathrm{Zn}$ and $\mathrm{Pb}$ are classified as traf-

Table 6: Contamination factor (CF) of PTMs in soil samples of Touggourt industrial area.

\begin{tabular}{|lllllll|}
\hline Sampling & \multicolumn{5}{c|}{ Metal } \\
\cline { 2 - 6 } Site & $\mathrm{Zn}$ & $\mathrm{Fe}$ & $\mathrm{Co}$ & $\mathrm{Cu}$ & $\mathrm{Pb}$ & $\mathrm{Mn}$ \\
\hline S1 & 0.168 & 0.156 & 0.044 & 0.01 & 0.145 & 0.008 \\
S2 & 0.060 & 0.069 & 0.047 & 0.01 & 0.068 & 0.004 \\
S3 & 0.088 & 0.075 & 0.038 & 0.01 & 0.040 & 0.004 \\
S4 & 0.210 & 0.126 & 0.063 & 0.011 & 0.209 & 0.008 \\
S5 & 0.355 & 1.605 & 0.277 & 0.052 & 0.058 & 0.007 \\
S6 & 0.321 & 0.138 & 0.053 & 0.012 & 0.063 & 0.007 \\
S7 & 0.749 & 0.107 & 0.049 & 0.010 & 0.292 & 0.006 \\
S8 & 0.131 & 0.046 & 0.028 & 0.004 & 0.048 & 0.003 \\
S9 & 0.158 & 0.095 & 0.050 & 0.008 & 0.109 & 0.004 \\
S10 & 0.122 & 0.044 & 0.042 & 0.005 & 0.065 & 0.001 \\
S11 & 0.597 & 0.394 & 0.101 & 0.015 & 0.438 & 0.029 \\
S12 & 0.605 & 0.106 & 0.035 & 0.025 & 0.494 & 0.003 \\
S13 & 0.234 & 0.059 & 0.033 & 0.005 & 0.155 & 0.004 \\
S14 & 0.075 & 0.089 & 0.037 & 0.006 & 0.081 & 0.002 \\
S15 & 0.128 & 0.063 & 0.036 & 0.011 & 0.222 & 0.004 \\
S16 & 0.080 & 0.057 & 0.037 & 0.006 & 0.082 & 0.004 \\
S17 & 0.319 & 0.165 & 0.092 & 0.019 & 0.216 & 0.010 \\
S18 & 0.121 & 0.015 & 0.074 & 0.007 & 0.245 & 0.002 \\
\hline
\end{tabular}

Table 7: The average and range of contamination factor (CF) values of PTMs in soil samples of Touggourt industrial area.

\begin{tabular}{|llll|}
\hline Metal & & Contamination factor (CF) value & Category \\
\hline $\mathrm{Zn}$ & Range & Average & Low contamination factor \\
$\mathrm{Fe}$ & $0.06-0.749$ & 0.244 & $/ /$ \\
$\mathrm{Co}$ & $0.015-1.6015$ & 0.189 & $/ /$ \\
$\mathrm{Cu}$ & $0.028-0.277$ & 0.059 & $/ /$ \\
$\mathrm{Pb}$ & $0.004-0.052$ & 0.012 & $/ /$ \\
$\mathrm{Mn}$ & $0.040-0.494$ & 0.155 & $/ /$ \\
\hline
\end{tabular}


Table 8: Pollution load index (PLI) of PTMs in soil samples of Touggourt industrial area.

\begin{tabular}{|c|c|c|c|c|c|c|c|}
\hline Sampling site & CF Zn & $\mathrm{CF} \mathrm{Fe}$ & $\mathrm{CF}$ Co & $\mathrm{CF} \mathrm{Cu}$ & $\mathrm{CF} \mathrm{Pb}$ & CF Mn & PLI value \\
\hline S1 & 0.168 & 0.156 & 0.044 & 0.010 & 0.145 & 0.008 & 0.055 \\
\hline S2 & 0.060 & 0.069 & 0.047 & 0.010 & 0.068 & 0.004 & 0.033 \\
\hline S3 & 0.088 & 0.075 & 0.038 & 0.010 & 0.040 & 0.004 & 0.031 \\
\hline S4 & 0.210 & 0.123 & 0.063 & 0.011 & 0.209 & 0.008 & 0.063 \\
\hline S5 & 0.355 & 1.605 & 0.277 & 0.052 & 0.058 & 0.007 & 0.133 \\
\hline S6 & 0.321 & 0.138 & 0.053 & 0.012 & 0.063 & 0.007 & 0.054 \\
\hline S7 & 0.749 & 0.107 & 0.049 & 0.010 & 0.292 & 0.006 & 0.071 \\
\hline S8 & 0.131 & 0.046 & 0.028 & 0.004 & 0.048 & 0.003 & 0.025 \\
\hline S9 & 0.158 & 0.095 & 0.050 & 0.008 & 0.109 & 0.004 & 0.042 \\
\hline S10 & 0.122 & 0.044 & 0.042 & 0.005 & 0.065 & 0.001 & 0.024 \\
\hline S11 & 0.597 & 0.394 & 0.101 & 0.015 & 0.438 & 0.029 & 0.139 \\
\hline $\mathrm{S} 12$ & 0.605 & 0.106 & 0.035 & 0.025 & 0.494 & 0.003 & 0.074 \\
\hline S13 & 0.234 & 0.059 & 0.033 & 0.005 & 0.155 & 0.004 & 0.038 \\
\hline S14 & 0.075 & 0.089 & 0.037 & 0.006 & 0.081 & 0.002 & 0.029 \\
\hline S15 & 0.128 & 0.063 & 0.036 & 0.011 & 0.222 & 0.004 & 0.043 \\
\hline S16 & 0.080 & 0.057 & 0.037 & 0.006 & 0.082 & 0.004 & 0.030 \\
\hline S17 & 0.319 & 0.165 & 0.092 & 0.019 & 0.216 & 0.010 & 0.085 \\
\hline S18 & 0.121 & 0.015 & 0.074 & 0.007 & 0.245 & 0.002 & 0.032 \\
\hline
\end{tabular}

Table 9: Enrichment factor (EF) of PTMs in soil samples of Touggourt industrial area.

\begin{tabular}{|llllll|}
\hline Sampling & \multicolumn{5}{l}{ Metal } \\
\cline { 2 - 6 } site & $\mathrm{Zn}$ & $\mathrm{Mn}$ & $\mathrm{Co}$ & $\mathrm{Cu}$ & $\mathrm{Pb}$ \\
\hline S1 & 1.079 & 0.052 & 0.286 & 0.059 & 0.924 \\
S2 & 0.868 & 0.062 & 0.679 & 0.131 & 0.980 \\
S3 & 1.184 & 0.057 & 0.511 & 0.108 & 0.534 \\
S4 & 1.678 & 0.066 & 0.506 & 0.093 & 1.669 \\
S5 & 0.221 & 0.004 & 0.173 & 0.033 & 0.036 \\
S6 & 2.326 & 0.057 & 0.389 & 0.093 & 0.452 \\
S7 & 7.162 & 0.057 & 0.477 & 0.100 & 2.786 \\
S8 & 2.812 & 0.054 & 0.609 & 0.101 & 1.019 \\
S9 & 1.653 & 0.038 & 0.531 & 0.093 & 1.146 \\
S10 & 2.737 & 0.030 & 0.952 & 0.119 & 1.464 \\
S11 & 1.514 & 0.073 & 0.256 & 0.040 & 1.110 \\
S12 & 5.708 & 0.032 & 0.330 & 0.239 & 4.661 \\
S13 & 3.953 & 0.072 & 0.570 & 0.088 & 2.613 \\
S14 & 0.837 & 0.018 & 0.415 & 0.065 & 0.912 \\
S15 & 2.020 & 0.067 & 0.576 & 0.165 & 3.494 \\
S16 & 1.394 & 0.067 & 0.655 & 0.110 & 1.428 \\
S17 & 1.935 & 0.063 & 0.562 & 0.117 & 1.314 \\
S18 & 7.866 & 0.152 & 4.844 & 0.439 & 15.909 \\
\hline
\end{tabular}

fic-related metals that are the products of vehicle emission and/or mechanical wear of parts of cars (e.g. brake discs and tires). The $\mathrm{EF}$ value of $\mathrm{Pb}$ and $\mathrm{Zn}$ is found $>1$ in most of the sampling sites, suggesting that heavy traffic contributes to higher enrichment of $\mathrm{Zn}$ and $\mathrm{Pb}$ in the study area (Dytłow \& Górka-Kostrubiec 2020).

\section{CONCLUSION}

The study area is characterized by a significant number of productive facilities. It is well known that any industrial activity must leave a mark on the environmental resources surrounding it and the topsoil is surely one of the most affected resources by such industrial activities. Therefore, this current study has concluded that the study's soils content of PTMs exceeds the permissible limit, although the contamination factor results fall into the low contamination category, besides the pollution load index results, which need more detailed study. The fact that the pollution index values are in the low range does not imply that there is no contamination; rather, it reflects the high PTMs content in the reference soil, which is extremely near to the PTMs level in the study's soil samples. Hence, the most important conclusion from this study is that the anthropogenic activities are the major sources of the PTMs concentrations in the soil of the study area as shown in the computed pollution indices and this is 
Table 10: The average and range of enrichment factor (EF) values of PTMs in soil samples of Touggourt industrial area.

\begin{tabular}{|llll|}
\hline Metal & \multicolumn{2}{c|}{ Enrichment factor $(\mathrm{CF})$ value } & Category \\
\hline & Range & Average & \\
\hline $\mathrm{Zn}$ & $0.221-7.866$ & 2.608 & Moderate enrichment \\
$\mathrm{Co}$ & $0.173-4.844$ & 0.740 & Deficiency to minimal enrichment \\
$\mathrm{Cu}$ & $0.040-0.439$ & 0.122 & Deficiency to minimal enrichment \\
$\mathrm{Pb}$ & $0.036-15.909$ & 2.358 & Moderate enrichment \\
$\mathrm{Mn}$ & $0.004-0.152$ & 0.060 & Deficiency to minimal enrichment \\
\hline
\end{tabular}

reflected by the results of the Enrichment Factor, the main factor among the environmental pollution indices, which showed the deterioration in the soil of the study area. Detailed in-depth investigation regarding physicochemical properties of Touggourt industrial soil, bioavailable metal fractions in it, and associated health risks are still required.

\section{ACKNOWLEDGEMENT}

The authors would like to thank the Algerian Ministry of Higher Education and Scientific Research and General Directorate of Scientific Research and Technological Development (DGRSDT) for their support and providing the necessary facilities to carry out this research.

\section{REFERENCES}

Abdelhamid, I.Q. 1999. Definition of Oued Righ, In the Publication of Elwaffa llshahid Organization, Touugourt, Elamal for Printing, Oued Souf.

Abrahim, G. and Parker, R. 2008. Assessment of heavy metal enrichment factors and the degree of contamination in marine sediments from Tamaki estuary, Auckland, New Zealand. Environ. Monit. Assess., 136: 227-38.

Adamo, P., Agrelli, D. and Zampella, M. 2018. Chapter 9 - Chemical Speciation to Assess Bioavailability, Bioaccessibility, and Geochemical Forms of Potentially Toxic Metals (PTMs) in Polluted Soils. In De Vivo, B., Belkin, H.E. and Lima, A. (eds), Environmental Geochemistry (Second Edition). Elsevier, The Netherlands, pp. 153-94.

Adamo, P., Arienzo, M., Imperato, M. Naimo, D. and Nardi, M. 2005. Distribution and partition of heavy metals in surface and sub-surface sediments of Naples city port. Chemosphere, 61: 800-9. https://doi. org/10.1016/j.chemosphere.2005.04.001.

Adamu, S., Mangs, A., Murtala, A. and Lar, U. 2014. Assessment of potentially toxic metals in soil and sediments of the Keana Brinefield in the Middle Benue Trough, Northcentral Nigeria. Am. J. Environ. Prot., 3: 6-12.

Akoto, O., Bruce, T. and Darko, G. 2008. Heavy metals pollution profiles in streams serving the Owabi reservoir. Afr. J. Environ. Sci. Technol., 2: 354-359

Ayangbenro, A.S. and Babalola, O.O. 2017. A new strategy for heavy metal polluted environments: A review of microbial biosorbents. Int. J. Environ. Res. Public Health, 14: 94.

Barkett, M.O. and Akün, E. 2018. Heavy metal contents of contaminated soils and ecological risk assessment in abandoned copper mine harbor in Yedidalga, Northern Cyprus. Environ. Earth Sci., 77: 378.

Boulghobra, N., N. Koull, and T. Benzaoui 2016. Four decades period of climatic data for assessing the aeolian hazard in the region of Touggourt
(Low Algerian Sahara). Geographia Technica 11: 13-22. 10.21163/ GT_2016.111.03.

Chandrasekaran, A., Ravisankar, R., Harikrishnan, N., Satapathy, K.K. and Prasad, M.V.R. 2015. Multivariate statistical analysis of heavy metal concentration in soils of Yelagiri Hills, Tamilnadu, India: Spectroscopical approach. Spectrochim. Acta. A, 137: 589-600.

Chen, S., Wu, C., Hong, S. and Chen, Q. 2020. Assessment, distribution and regional geochemical baseline of heavy metals in soils of densely populated area: A case study. Int. J. Environ. Res. Public Health, 17: 22-69.

Chen, T.B., Wong, J.W.C., Zhou, H.Y. and Wong, M.H. 1997. Assessment of trace metal distribution and contamination in surface soils of Hong Kong. Environ. Pollut., 96: 61-8.

Daniel, P. 1978. Systems of nomadic relations: Touggourt region, Algeria. $\mathrm{PhD}$ Thesis, High School of Social Sciences, France.

Dehghani, S., Moore, F., Keshavarzi, B. and Hale, B.A. 2017. Health risk implications of potentially toxic metals in street dust and surface soil of Tehran, Iran. Ecotoxicol. Environ. Safety, 136: 92-103.

Dytłow, S. and Górka-Kostrubiec, B. 2020. The concentration of heavy metals in street dust: an implication of using different geochemical background data in estimating the level of heavy metal pollution. Environ. Geochem. Health, 26: 726-735.

E, A. The Tomllinson Pollution Load Index Applied to Heavy Metals "Mussel-Watch" Data: A Useful Index to Assess Coastal Pollution. Sci. Total. Environ. 1996;187: 19-56.

Fang, T.H. and Lin, C.L. 2002. Dissolved and particulate trace metals and their partitioning in a hypoxic estuary: The Tanshui Estuary in Northern Taiwan. Estuaries, 25: 598-607.

Galindo, N., M. Varea, J. Gil-Moltó, E. Yubero, and J. Nicolás 2011. The Influence of Meteorology on Particulate Matter Concentrations at an Urban Mediterranean Location. Water, Air, \& Soil Pollution 215: $365-$ 72. 10.1007/s11270-010-0484-z.

Gałuszka, A. and Migaszewski, Z. 2011. Geochemical background: An environmental perspective. Mineralogia, 42: 7-17.

Gong, Q., Deng, J., Yunchuan, X., Qingfei, W. and Yang, L. 2008 Calculating pollution indices by heavy metals in ecological geochemistry assessment: A case study in Parks of Beijing. J. China Univ. Geosci., 19: $230-241$

Hakanson, L. 1980. An ecological risk index for aquatic pollution control: A sedimentological approach. Water Res., 14: 975-1001.

Hossain, M.A., Ali, N.M., Islam, M.S. and Hossain, H.M.Z. 2015. Spatial distribution and source apportionment of heavy metals in soils of Gebeng industrial city, Malaysia. Environ. Earth Sci., 73: 115-126.

Kabata-Pendias, A., Mukherjee,C. and Arun, B. 2007. Trace Elements from Soil to Human. Springer-Verlag, Berlin Heidelberg.

Kelly, J., Thornton, I. and Simpson, P.R. 1996. Urban geochemistry: A study of the influence of anthropogenic activity on the heavy metal content of soils in traditionally industrial and non-industrial areas of Britain. Appl. Geochem., 11: 363-70.

Keshav, K. A. and Rama, K.M. 2016. Distribution, correlation, ecological and health risk assessment of heavy metal contamination in surface 
soils around an industrial area, Hyderabad, India. Environ. Earth Sci., 75: 411.

Likuku, S., Mmolawa, K. and Gaboutloeloe, G. 2013. Assessment of heavy metal enrichment and degree of contamination around the copper-nickel mine in the Selebi Phikwe region, Eastern Botswana. Environ. Ecol. Res., 1: 32-40.

Liu, W.H., Zhao, J.Z., Ouyang, Z.Y., Söderlund, L. and Liu, G.H. 2005. Impacts of sewage irrigation on heavy metal distribution and contamination in Beijing, China. Environ. Int. 31: 805-12. https://doi. org/10.1016/j.envint.2005.05.042.

Manta, D.S., Angelone, M., Bellanca, R. Neri, and M. Sprovieri, M. 2002. Heavy metals in urban soils: a case study from the city of Palermo (Sicily), Italy. Science of The Total Environment 300: 229-43. https:// doi.org/10.1016/S0048-9697(02)00273-5.

Mmolawa, K., Likuku, S. and Gaboutloeloe, G. 2010. Assessment of heavy metal pollution in soils along major roadside areas in Botswana. Afr. J. Environ. Sci. Technol., 5: 221-239

Muller, G. 1969. Index of geo accumulation in sediments of the Rhine River. Geol. J., 2: 109-118.

National Office of Meteorology Algeria (NOMA). 2019. Meteorological Data. Regional Department of Touggourt, Algeria.

OJPDRA 2006. Official Journal of the People's Democratic Republic of Algeria $\mathrm{N}^{\circ} 24$ (Executive decree of April 15, 2006)

Ozkan, E., Bir, E., İzmir, K., Körfez, İ. and Metal, A. 2012. A new assessment of heavy metal contaminations in a eutrophicated bay (Inner Izmir Bay, Turkey). Turk. J. Fish. Aquat. Sci., 12: 135-147.

Pobi, K.K., Nayek, S., Gope, M., Rai, A.K. and Saha, R. 2020. Sources evaluation, ecological and health risk assessment of potentially toxic metals (PTMs) in surface soils of an industrial area, India. Environ. Geochem. Health, 10: 517-522.

Santos, A., Alonso, E., Callejón, M. and Jiménez, J.C. 2002. Heavy metal content and speciation in groundwater of the Guadiamar river basin. Chemosphere, 48: 279-85.
Schiff, K.C. and Weisberg, S.B. 1999. Iron as a reference element for determining trace metal enrichment in Southern California coastal shelf sediments. Marine Environ. Res., 48: 161-76.

Silva, Y.J.A.B.D., Cantalice, J.R.B., Singh, V.P., Nascimento, C.W.A.D. and Wilcox, B.P. 2019. Heavy metal concentrations and ecological risk assessment of the suspended sediments of a multi-contaminated Brazilian watershed. Acta Sci. Agron., 41: 132-143

Szefer, P., Szefer, K., Glasby, G.P., Pempkowiak, J. and Kaliszan, R. 2008. Heavy-metal pollution in surficial sediments from the Southern Baltic Sea off Poland. J. Environ. Sci. Health, 31: 2723-2754.

Usero, U., Garcia, A. and Fraidias, J. 2000. Quality of the waters and sediments of the Andalusian Coast. In: Sevilla, M. (ed.), Junta de Andalicia, 17: 164.

Victoria, A., S. Cobbina, S. Dampare, and A. Duwiejuah 2014. Heavy Metals Concentration in Road Dust in the Bolgatanga Municipality, Ghana. Int J Environ Res Public Health.

Wang, G., Zhang, S., Xiao, L., Zhong, Q. and Li, L. 2017. Heavy metals in soils from a typical industrial area in Sichuan, China: Spatial distribution, source identification, and ecological risk assessment. Environ. Sci. Pollut. Res. Int., 24: 16618-30.

Woitke, P., Wellmitz, J., Helm, D., Kube, P. and Lepom, P. 2003. Analysis and assessment of heavy metal pollution in suspended solids and sediments of the river Danube. Chemosphere, 51: 633-42.

Wuana, R.A. and Okieimen, F.E. 2011. Heavy metals in contaminated soils: A review of sources, chemistry, risks and best available strategies for remediation. ISRN Ecol., 2011: 20.

Zakir, H., Naotatsu, S. and Kazuo, O. 2008. Geochemical distribution of trace metals and assessment of anthropogenic pollution in sediments of Old Nakagawa River, Tokyo, Japan. Am. J. Environ. Sci., 4: 654-665.

Zheljazkov, V.D. and Nielsen, N.E. 1996. Effect of heavy metals on peppermint and corn mint. Plant Soil, 178: 59-66. 